\title{
MDR-1 and MRP2 gene polymorphisms in Mexican epileptic pediatric patients with complex partial seizures
}

\section{David Escalante-Santiago ${ }^{1,2}$, Iris Angélica Feria-Romero ${ }^{2}$, Rosa María Ribas-Aparicio ${ }^{1}$, Dario Rayo-Mares ${ }^{3}$, Pietro Fagiolino ${ }^{4}$, Marta Vázquez ${ }^{4}$, Consuelo Escamilla-Núñez ${ }^{5}$, Israel Grijalva-Otero ${ }^{2}$, Miguel Angel López-García ${ }^{2}$ and Sandra Orozco-Suárez ${ }^{2 *}$}

\author{
1 Programa de Biomedicina y Biotecnología Molecular, Escuela Nacional de Ciencias Biológicas del Instituto Politécnico Nacional, Mexico City, Mexico \\ 2 Unidad de Investigación Médica en Enfermedades Neurológicas, Hospital de Especialidades, Centro Médico Nacional Siglo XXI, Instituto Mexicano del Seguro \\ Social, Mexico City, Mexico \\ ${ }^{3}$ Neurología, Hospital de Pediatría, Centro Médico Nacional Siglo XXI, Instituto Mexicano del Seguro Social, Mexico City, Mexico \\ ${ }^{4}$ Departamento de Ciencias Farmacéuticas de la Facultad de Química, Universidad de la República, Montevideo, Uruguay \\ ${ }^{5}$ Instituto Nacional de Salude Publica, Cuernavaca, Mexico
}

\section{Edited by:}

Fernando Cendes, University of Campinas, Brazil

\section{Reviewed by:}

Marilisa M Guerreiro, University of Campinas, Brazil

Rodrigo Secolin, University of Campinas, Brazil

*Correspondence:

Sandra Orozco-Suárez, Unidad de Investigación Médica en

Enfermedades Neurológicas, Hospital de Especialidades, Centro Médico Nacional Siglo XXI, IMSS. Av Cuauhtémoc No. 330-4, Col. Doctores, 06720-25, Mexico city, Mexico

e-mail:sorozco5@hotmail.com
Although the Pgp efflux transport protein is overexpressed in resected tissue of patients with epilepsy, the presence of polymorphisms in MDR1/ABCB1 and MRP2/ABCC2 in patients with antiepileptic-drugs resistant epilepsy (ADR) is controversial. The aim of this study was to perform an exploratory study to identify nucleotide changes and search new and reported mutations in patients with ADR and patients with good response (CTR) to antiepileptic drugs (AEDs) in a rigorously selected population. We analyzed 22 samples In Material and Methods, from drug-resistant patients with epilepsy and 7 samples from patients with good response to AEDs. Genomic DNA was obtained from leukocytes. Eleven exons in both genes were genotyped. The concentration of drugs in saliva and plasma was determined. The concentration of valproic acid in saliva was lower in ADR than in CRT. In $A B C B 1$, five reported SNPs and five unreported nucleotide changes were identified; rs2229109 (GA) and rs2032582 (AT and AG) were found only in the ADR. Of six SNPs associated with the $A B C C 2$ that were found in the study population, rs3740066 (TT) and $66744 T>A$ (TG) were found only in the ADR. The strongest risk factor in the $A B C B 1$ gene was identified as the TA genotype of rs2032582, whereas for the $A B C C 2$ gene the strongest risk factor was the T allele of rs3740066. The screening of SNPs in ACBC1 and $A B C C 2$ indicates that the Mexican patients with epilepsy in this study display frequently reported $A B C C 1$ polymorphisms; however, in the study subjects with a higher risk factor for drug resistance, new nucleotide changes were found in the $A B C C 2$ gene. Thus, the population of Mexican patients with AED-resistant epilepsy (ADR) used in this study exhibits genetic variability with respect to those reported in other study populations; however, it is necessary to explore this polymorphism in a larger population of patients with ADR.

Keywords: drug-resistant, epilepsy, $A B C B 1, A B C C 2$, Mexican patients, single-nucleotide polymorphisms, anti-epileptic drugs

\section{INTRODUCTION}

Epilepsy is a chronic non-communicable disorder of the brain that affects approximately 70 million people worldwide $(1,2)$. The administration of anti-epileptic drugs (AEDs) is the treatment of choice. In $30 \%$ of patients with epilepsy, seizures persist despite polytherapy with more than one AED, adequate monitoring of serum drug levels and the watchful care of a neurologist (3). Hence, the timely identification of patients who do not respond favorably to AEDs is crucial because these patients are affected both by the treatment and by continuing seizures. Although the pathophysiological basis of drug resistance in epilepsy is not clear, some mechanisms for this resistance have been proposed. Following seizures, the overexpression of drug-transporter proteins in the blood brain barrier (BBB) could be mediated by the nuclear receptor PXR (4); alternatively, polymorphisms in these proteins could abrogate their function. The main function of carrier proteins is to allow the passage of compounds through biological barriers such as the BBB. Using ATP, the ABC transporter family of proteins actively transports a wide variety of compounds, including toxins and xenobiotics, across cell membranes. $\mathrm{ABC}$ transporter proteins have two functional domains. The first domain is anchored to the cell membrane by its alpha-helical structure; the second, which is a nucleotide-binding domain (NBD), binds ATP, which provides the energy necessary for the conformational change that result in transport of the compound across the membrane. All ABC transporters have at least two transmembrane domains and two NBDs that are highly conserved between species (5).

MDR-1 (P-glycoprotein or P-gp) is an ATP-dependent efflux pump protein that controls the flow of toxins and drugs such as felbamate (FBM), gabapentin (GBP), lamotrigine (LTG), 
phenytoin (PTH), and topiramate (TPM) into the brain (6-9). The gene encoding MDR-1 is $A B C B 1$, which is located on chromosome 7q21.12 and consists of 209,461 base pairs (bp) and 29 exons (NCBI reference sequence NG_011513.1). The most extensively studied single-nucleotide polymorphisms (SNPs) in the $A B C B 1$ gene are rs1128503 (C1236T), rs2032582 (G2677T/A), and rs1045642 (C3435T); the latter has received increased attention as a critical variable in resistance to AEDs (10-16) MRP2 is another efflux transporter protein present in the $\mathrm{BBB}$. Its gene, $A B C C 2$, is located on chromosome 10q24 and contains 69,000 bp representing 33 exons (NG_011798.1). The MRP2 transporter protein recognizes CBZ, LTG, and FBM; its most relevant polymorphisms are rs2273697 (G1249A) and rs3740066 (C3972T). The latter polymorphism reduces the transport of carbamazepine (17-20). The aim of this study was to perform a non-inferential exploratory study to identify reported nucleotide changes and explore new ones in a rigorously selected Mexican population of patients with AED-resistant epilepsy (ADR) and patients with good response to AEDs (CTR).

\section{MATERIALS AND METHODS \\ PATIENTS AND SAMPLE COLLECTION}

This project was approved by the National Research Committee of the Instituto Mexicano del Seguro Social (Mexican Social Security Institute, IMSS). An observational study with 22 patients with ADR (cases) and 7 patients with good response to AEDs (controls) was performed, while avoiding inbreeding between the patient's biological parents.

The inclusion criteria for ADR were patients with demonstrable epileptic focus through EEG and radiological focal structural lesion to discard and classified as resistant to pharmacological treatment, treated with two or more drugs (Table 1) at appropriate doses, serum levels within therapeutic range for at least 6 months of continuous treatment, and under the supervision of a neurologist pediatrician, with a frequency of three seizures per month, who attend Neurology Service, Hospital of Pediatrics, National Medical Center, Century XXI, who is of Mexican origin like their parents and grandparents, from 1 to 16 years of age, both genders, whereas for asymptomatic control patients was seizure-free for at least 6 months before the study.

Both groups had complex partial seizures, showed similar clinical variables, were previously selected under medical supervision, and gave written informed consent. Exclusion criteria were all types of seizures that are not complex partial, little adherence to treatment.

A total of $15 \mathrm{ml}$ of blood was collected from each patient via antecubital vein using an EDTA tube, and two fractions of 0.5$2.0 \mathrm{ml}$ of saliva were collected upon stimulation with citric acid. Samples that were used to monitor drug concentrations were taken before the first dose in the morning.

\section{AMPLIFICATION AND SEQUENCING}

Genomic DNA was extracted from leukocytes in patient blood samples using a commercial kit (Genomic DNA Purification kit, Thermo Scientific ${ }^{\circledR}$, USA), according to the supplier's recommendations. The polymorphisms (SNPs) from exons 1 (rs9282564), 10

Table 1 | Demographics and clinical data of patients with AEDs-resistant epilepsy and patients with good response to AEDs.

\begin{tabular}{lll}
\hline Clinical data & ADR
\end{tabular}

Age (years $\pm S D$ ), range

Gender (F/M)

Onset of seizures

Number of seizures/month

Years of seizures

Controlled time

(years $\pm \mathrm{SD}$ ) range

\section{Valproic Ac. dose (mg/day)}

Valproic Ac. concentration/saliva (mg/l)

Valproic Ac.

concentration/plasma

(mg/l)

\section{Carbamacepine dose (mg/day)}

Carbamacepine

concentration/saliva (mg/l)

Carbamacepine

concentration/plasma

(mg/l)

Phenytoin dose (mg/day)
Phenytoin

concentration/saliva (mg/l)

Phenytoin

concentration/plasma

(mg/l)

\section{Levetiracetam dose}

(mg/day)

Levetiracetam

concentration/saliva (mg/l)

Levetiracetam

concentration/plasma

(mg/l)

Mean $\pm S D$

F, female; $M$, male.

(rs2229109), 11 (rs1128503), 13 (rs28381902), 20 (rs2032582), and 25 (rs1045642) were located in GenBank accession CCDS5608.1, corresponding to the $A B C B 1$ gene, and exons 10 (rs2273697), 25 (rs8187692, rs17222723), 28 (rs3740066), 29 (rs7899457), and 32 (rs8187710) were located in GenBank accession CCDS7484.1, corresponding to the $A B C C 2$ gene. These polymorphisms were selected based on their frequency in the Hispanic or Mexican population, as noted in NCBI GenBank. Each amplification reaction was performed with $5 \mu \mathrm{l}(5 \mathrm{ng} / \mu \mathrm{l})$ of genomic DNA in a $50 \mu \mathrm{l}$ total reaction volume containing $5 \mu \mathrm{l}$ of $10 \times$ reaction buffer, $\mathrm{MgCl}_{2}$ (concentration depending on the primer set), $1 \mu 110$ mMdNTPs 
(Thermo Scientific ${ }^{\circledR}$, USA), $1 \mu \mathrm{l}$ of each $10 \mathrm{mM}$ flanking primer (Invitrogen ${ }^{\circledR}, \mathrm{USA}$ ), and $1 \mu \mathrm{l}$ of Taq polymerase (Thermo Scientific $^{\circledR}$, USA). PCR was performed in a DNA engine system ${ }^{\circledR}$ thermocycler (Bio- $\operatorname{Rad}^{\circledR}, \mathrm{USA}$ ) with a cycle program at $94^{\circ} \mathrm{C}$ for $3 \mathrm{~min}$, 38 cycles of $94^{\circ} \mathrm{C}$ for $30 \mathrm{~s}, T_{h}^{\circ}$ for $35 \mathrm{~s}, 72^{\circ} \mathrm{C}$ for $35 \mathrm{~s}$, and one extension cycle of $10 \mathrm{~min}$ at $72^{\circ} \mathrm{C}$. The primers, $\mathrm{MgCI}_{2}$ concentration, and $T_{h}^{\circ}$ for each amplification reaction are listed in Table 2.

The amplification products were purified with the GeneJET Gel Extraction kit (Thermo Scientific ${ }^{\circledR}$, USA) and sequenced in a $5 \mu \mathrm{l}$ total reaction volume using $100 \mathrm{ng}$ of amplicon, Fw or Rv primer, and Big Dye 3.1 sequencing Ready Reaction Kit (Applied Biosystems, USA) according to the manufacturer's recommendations. Sequencing was performed in a DNA engine system ${ }^{\circledR}$ thermocycler (Bio-Rad ${ }^{\circledR}, \mathrm{USA}$ ) with a cycle program at $94^{\circ} \mathrm{C}$ for $1 \mathrm{~min}, 30$ cycles of $94^{\circ} \mathrm{C}$ for $10 \mathrm{~s}, 50^{\circ} \mathrm{C}$ for $5 \mathrm{~s}, 60^{\circ} \mathrm{C}$ for $4 \mathrm{~min}$, and finally the fragments were analyzed in Automated Sequencing ABI Prism 310 Gene Analyzer (Applied Biosystems, USA), previous purification with DyeEx 2.0 Spin Kit (Qiagen, Germany).

\section{DRUG MONITORING}

Plasma samples were used for VPA and CBZ detection by immunofluorescence with a polarized light system (FPIA, Dade Behring, USA), according to the supplier's recommendations.

Saliva samples were used to detection concentration of CBZ and PHT (determined by Axsym ${ }^{\circledR}$, Abbot Laboratories ${ }^{\circledR}$, USA) according to the supplier's recommendations, VPA, and LEV [determined by high performance liquid chromatography (HPLC)]. For VPA, $30 \mu \mathrm{l}$ of an internal standard solution (98\% octanoic acid diluted $1 / 500$ with methanol), $200 \mu \mathrm{l}$ of phosphoric acid, and $5 \mathrm{ml}$ of cyclohexane were added to $1 \mathrm{ml}$ of saliva and vortexed for $2 \mathrm{~min}$. After centrifugation, a back-extraction was performed by adding $100 \mu \mathrm{l}$ of $1 \%$ TEA to the organic phase supernatant. The mixture was vortexed and centrifuged. Finally, $20 \mu \mathrm{l}$ of the aqueous phase was directly injected into a Dionex Ultimate 3000 Series. A Phenomenex Luna $5 \mu \mathrm{m} \mathrm{CN}$ column $(15 \mathrm{~cm} \times 4.6 \mathrm{~mm})$ was used as the stationary phase. The mobile phase was a mixture of $40 \mathrm{mM}$ phosphate potassium, monobasic, $\mathrm{pH}$ 3.4: Acetonitrile (90:10). The column compartment was kept at $40^{\circ} \mathrm{C}$, and the wavelength of detection was $210 \mathrm{~nm}$. For LEV, $50 \mu \mathrm{l}$ of internal standard solution (diethylbarbituric acid, $12 \mathrm{mg} / \mathrm{l}$ ) was added to $500 \mu \mathrm{l}$ of saliva. For the extraction, $1.5 \mathrm{ml}$ of ethyl acetate was added, and the mixture was vortexed for $1 \mathrm{~min}$. After centrifugation, the supernatant was separated and dried under nitrogen stream at $37-40^{\circ} \mathrm{C}$. Dry residue was dissolved with $100 \mu \mathrm{l}$ of mobile phase, and $20 \mu \mathrm{l}$ was injected into a Shimadzu LC-6A.A Phenomenex ${ }^{\circledR}$ Luna C18 column $(5 \mu \mathrm{m}, 100 \AA, 150 \mathrm{~mm} \times 4.6 \mathrm{~mm})$, which was used as a reversed stationary phase. The mobile phase was a mixture of $50 \mathrm{mM}$ phosphate buffer and acetonitrile (72:8).

\section{STATISTICAL ANALYSIS}

Clinical data from patients were analyzed using non-parametric and unpaired tests $(p<0.05)$; allelic and genotype relative frequencies were analyzed using the Fisher exact test in Graph Pad Prism software version 4.00 (GraphpadPrisma Software Inc. ${ }^{\circledR}$ San Diego, CA, USA). Hardy-Weinberg equilibrium (HWE) values were derived from chi-square tests, and the association between odds ratios (ORs) and confidence intervals was determined using software available at http://ihg.gsf.de/cgi-bin/hw/hwal.pl.

\section{RESULTS}

\section{CLINICAL DATA}

Because previous studies suggest that external factors such as gender, age of onset, number of seizures, and other factors influence the response to AED treatment, the selection of a homogeneous population for the study was an important aspect of this work $(21,22)$. There was no significant difference in male: female frequency between the two groups used in the study. Neither the average age of the patients $(10.57 \pm 1.56$ for patients with good response to AEDs and $10.23 \pm 0.78$ for patients with ADR; $p=0.42$ ) or the average age of onset of seizures ( $4.57 \pm 1.43$ years in patients with good response to AEDs and $4.38 \pm 0.81$ patients with ADR; $p=0.34$ ) differed significantly. Furthermore, the average seizure-free time in patients with good response to AEDs was 1.9 years, while the average time with seizures in patients with ADR was 5.8 years with a frequency of 63.4 seizures per month. The AEDs VPA, CBZ, LTG, PHT, and LEV were used with relative frequencies of $0.71,0.14,0.29,0.0$, and 0.14 , respectively, in patients with good response to AEDs and with relative frequencies of $0.59,0.09,0.0,0.18$, and 0.23 , respectively, in patients with ADR. The most commonly used AED was VPA, but VPA and CBZ were prescribed to both groups (Table 1). The daily dose of VPA $(814.3 \pm 212.1 \mathrm{mg} /$ day in patients with good response to AEDs and $598.0 \pm 129.7 \mathrm{mg} /$ day in patients with ADR; $p=0.206$ ) was similar in the two groups. The two groups showed no significant difference in mean plasma VPA concentrations $(35.17 \pm 18.04 \mathrm{mg} / \mathrm{l}$ patients with good response to AEDs and $31.62 \pm 8.03 \mathrm{mg} / \mathrm{l}$ in patients with ADR; $p=0.42$ ); however, the average saliva drug concentration was lower in patients with ADR $(1.68 \pm 0.59 \mathrm{mg} / \mathrm{l}$ patients with good response to AEDs and $0.57 \pm 0.12 \mathrm{mg} / \mathrm{l}$ in patients with ADR; $p=0.01$ ).

\section{POLYMORPHISMS IN THE ABCB1 AND ABCC2 GENES IN HISPANIC AND MEXICAN POPULATIONS}

In this study, chromatograms from amplicons were analyzed to identify expected polymorphisms and to determine the relative frequencies of alleles and genotypes, as described in Table 3. For $A B C B 1$, only the polymorphisms rs2229109, rs1128503, rs28381902, rs2032582, and rs1045642, but not rs9282564, were detected, whereas rs3740066 but not rs2273697, rs8187692, rs17222723, rs7899457, or rs8187710 were found in $A B C C 2$ in our patients, unlike the Hispanic/Mexican populations initially selected by the NCBI GenBank. In addition to these known polymorphisms, we identified rs2214102, rs2235047, and rs2235048 of $A B C B 1$ by sequencing the entire fragment including the exon and parts of the introns.

Another comparison was made between the relative frequencies of the minor allele (MAF) in our population and in the population represented by the NCBI GenBank data. The most significant similarities were found in rs1128503 and rs3740066 in ADR and in rs1045642 and rs2235048 in CTR (Table 3).

An important aspect of genetic alteration is whether a nucleotide change results in a change in an amino acid residue and whether this, in turn, structurally modifies the protein. In 
Table 2 | Primers used on ABCB1 and ABCC2 fragments amplification.

\begin{tabular}{|c|c|c|c|c|c|c|}
\hline GEN & EXON & \multicolumn{2}{|c|}{ Primer } & $\mathrm{MgCl}_{2}(\mathrm{mM})$ & $T_{\mathrm{h}}^{\mathrm{o}}$ & Size (bp \\
\hline & 11 & 5'-ATTCGAAGAGTGGGCACAAA-3' & 5'-TCATСТСАССАТССССТСТGT-3' & 1.0 & 52 & 398 \\
\hline & 12 & 5'-ATTCGAAGAGTGGGCACAAA-3' & 5'-TCATСТСАССАТССССТСТGT-3' & 1.0 & 52 & 398 \\
\hline & 14 & 5'-TTGGGCTGTGTATAGGATTCC-3' & 5'-AAGCCTCACTGACCTTATCCA-3' & 1.5 & 55 & 274 \\
\hline & 26 & 5'-TGTGCTGGTCCTGAAGTTGAT-3' & 5'-TGGTCGAACACTTTCATCCCT-3' & 1.50 & 62 & 472 \\
\hline \multirow[t]{4}{*}{ ABCC2 } & 10 & 5'-TTAGGCATTGACCCTATCCA-3' & 5'-GCCCAAACTCCCATTAAGAA-3' & 1.25 & 56 & 366 \\
\hline & 25 & 5'-CGGGACTGGCTGATTCTTTA-3' & 5'-ATGGGTAAATACCCAGGGGAA-3' & 1.0 & 54 & 273 \\
\hline & 28 & 5'-TTCTATGACACGAGTCCTGGG-3' & 5'-CATCCAGGCCTTCCTTCACT-3' & 1.25 & 56 & 258 \\
\hline & 29 & 5'-CCCCAAGAATTATTTGTGGAA-3' & 5'-GCATGTGCCCGAGTAAGTT-3' & 1.5 & 57 & 238 \\
\hline
\end{tabular}

The primer design was performed using the web page http://www.yeastgenome.org/cgi-bin/web-primer, $\mathrm{T}_{\mathrm{h}}^{\circ}$ were selected by a temperature gradient, and $\mathrm{MgCl}_{2}$ concentration was selected initially with $2.0 \mathrm{mM}$ and performed gradually until obtained a single sharp band.

this respect, the SNPs rs2229109 and rs2032582 are of interest due to the possible modifications that they may produce in protein MDR1 (Table 3).

The relative frequencies of the studied alleles were also compared with their frequencies in the Hispanic and Mexican reference populations reported in the NCBI GenBank (Table 4). In our population, SNP rs2229109 in exon 10 of $A B C B 1$ occurred with a relative frequency of 0.09 and was only present in heterozygous form in the ADR group (Table 3). Although a reference for the Mexican population was not available, we observed that our results showed a twofold higher minor allele frequency with respect to sample ss48292345 from the Hispanic population $(0.043)$ in a similar number of individuals (Table 4). The SNPs rs1128503 and rs2032582 in exons 11 and 20, respectively, of the $A B C B 1$ gene showed similar relative frequencies in the CTR (0.71) and ADR (0.82) patient groups; however, there was a difference in the frequencies of homozygotes and heterozygotes in the CTR group (Table 3). Furthermore, there were no Mexican individuals with AG heterozygous mutations in SNP rs2032582, and the AT heterozygous mutation was absent from both populations (Table 4).

In studies of patients with ADR, SNP rs1045642 in exon 25 has been shown to be relevant in association studies with drug resistant; in our population, the relative frequencies of this SNP were similar in the CTR and ARE groups at both the allelic and the genotypic levels. Furthermore, the SNPs rs2235047 and rs2235048 were identified in an intron between exons 25 and 26. The heterozygous form of rs2235047 showed a higher frequency ADR than in CTR ( 0.400 vs. 0.286 ), as seen in Table 3; however, the most outstanding difference in this SNP was in comparison to reference populations, relative to which it was more than three times as frequent (Table 4); this is more significant in our population than rs 1045642. The relative frequency of SNP rs2235048 was the same as that of rs1045642; when SNP rs1045642 showed the TT, TC, or CC genotype, we found the genotype CC, CT, or TT, respectively, in the position of SNP rs2235048. This association may be relevant to our population, which so far has not shown a clear similarity to reference populations.

SNP rs3740066 in exon 28 of the $A B C C 2$ gene occurred with a relative frequency of 0.13 as a heterozygous polymorphism in the controlled group and with a relative frequency of 0.41 as homozygous and heterozygous polymorphisms in the drugresistant group; the observed heterozygous ratio (ADR: CTR) was $2: 1$. In addition, the unexpected SNP rs2214102 located in the $5^{\prime} \mathrm{UTR}$ region of the $A B C B 1$ gene was present in the homozygous form in both groups; only $5 \%$ of the drug-resistant patients had the heterozygous form. However, this finding is not relevant because it is similar to a previous report in a Mexican population.

Some other differences observed in this study are worth noting. At SNP rs2032582, the allelic and genotypic distribution in the controlled group was more similar to reported populations in NCBI GenBank than was that of the ADR; in particular, the heterozygous $\mathrm{A}>\mathrm{T}$ mutation was not found in other populations similar to ours. Furthermore, although allele A of SNP rs2229109 was present at a lower frequency, our population showed an allele frequency more than 2.5-fold greater than the reported MAF (0.045 vs. 0.017$)$.

\section{NEW POLYMORPHISMS OF THE ABCC2 GENE IN MEXICAN EPILEPTIC PEDIATRIC PATIENTS}

By sequencing amplicons from exons 28 and 29 of the $A B C B 1$ and $A B C C 2$ genes, we found other single-nucleotide changes (SNCs) that have not been reported in the NCBI GenBank database (Table 2, RefSeqGene NG_011798.1). The SNC located in position $66744 \mathrm{~T}>\mathrm{G}$ adjacent to rs3740066 in exon 28 is present as a homozygous wild-type or heterozygous mutation, allowing the formation of four different triplets: ATC, ATT, AGT, and AGC. The ATC and ATT triplets, which show relative frequencies of 0.929 and 0.682 for triplet ATC and 0.071 and 0.205 for triplet ATT in CTR and ADR, respectively, are not associated with an amino acid change (Ile1324Ile). The AGT and AGC triplets produce an amino acid change (Ile1324Ser, Figure 1A); these occur 
Table 3 | Genotype and allelic relative frequencies of SNPs, MAF value, amino acid changes, and OR found in $A B C B 1$ and $A B C C 2$ genes.

\begin{tabular}{|c|c|c|c|c|c|c|c|c|c|c|}
\hline \multirow[t]{3}{*}{ Gene } & \multirow[t]{3}{*}{ SNP } & \multirow[t]{3}{*}{ Sample } & \multirow{3}{*}{$\begin{array}{l}\text { Allele } \\
\text { frequency }\end{array}$} & \multirow{3}{*}{$\begin{array}{l}\text { Genotype } \\
\text { frequency }\end{array}$} & \multirow[t]{3}{*}{ MAF } & \multicolumn{2}{|c|}{ Protein association } & \multicolumn{3}{|c|}{ Odds ratio } \\
\hline & & & & & & \multirow[t]{2}{*}{ aa, change } & \multirow[t]{2}{*}{ Localization } & \multirow[t]{2}{*}{ Allele } & \multicolumn{2}{|c|}{ Genotype } \\
\hline & & & & & & & & & Heterozogous & Homozygous \\
\hline \multirow[t]{6}{*}{$A B C B 1$} & rs2214102 & $\begin{array}{l}\text { CTR } \\
\text { ADR }\end{array}$ & $\begin{aligned} G & =1.000 \\
G & =0.971 \\
A & =0.029\end{aligned}$ & $\begin{aligned} G / G & =1.000 \\
G / G & =0.955 \\
G / A & =0.045\end{aligned}$ & $A=0.040 / 88$ & $5^{\prime}$ UTF & region & {$[G] \leftrightarrow[A], 2.446$} & {$[\mathrm{GG}] \leftrightarrow[\mathrm{GA}], 2.692$} & {$[\mathrm{GG}] \leftrightarrow[\mathrm{AA}], 0.385$} \\
\hline & rs2229109 & $\begin{array}{l}\text { CTR } \\
\text { ADR }\end{array}$ & $\begin{array}{l}G=1.000 \\
G=0.955 \\
A=0.045\end{array}$ & $\begin{aligned} \mathrm{G} / \mathrm{G} & =1.000 \\
\mathrm{G} / \mathrm{G} & =0.909 \\
\mathrm{G} / \mathrm{A} & =0.091\end{aligned}$ & $A=0.017 / 36$ & 400; G > A; Ser > Asn & $\begin{array}{l}\text { Cytoplasmatic; binding } \\
\text { site; Second domain }\end{array}$ & {$[G] \leftrightarrow[A], 1.706$} & {$[\mathrm{GG}] \leftrightarrow[\mathrm{GA}], 1.829$} & {$[\mathrm{GG}] \leftrightarrow[\mathrm{AA}], 0.366$} \\
\hline & rs1128503 & $\begin{array}{l}\text { CTR } \\
\text { ADR }\end{array}$ & $\begin{array}{l}T=0.571 \\
C=0.429 \\
T=0.455 \\
C=0.545\end{array}$ & $\begin{array}{l}\mathrm{C} / \mathrm{T}=0.571 \\
\mathrm{~T} / \mathrm{T}=0.286 \\
\mathrm{C} / \mathrm{C}=0.143 \\
\mathrm{C} / \mathrm{T}=0.545 \\
\mathrm{~T} / \mathrm{T}=0.182 \\
\mathrm{C} / \mathrm{C}=0.273\end{array}$ & $T=0.422 / 919$ & $412 ; \mathrm{T}>\mathrm{C} ;$ Gly > Gly & $\begin{array}{l}\text { Cytoplasmatic; beta } \\
\text { chain; second domain }\end{array}$ & {$[T] \leftrightarrow[C], 1.543$} & {$[\mathrm{TT}] \leftrightarrow[\mathrm{TC}], 1.200$} & {$[\mathrm{TT}] \leftrightarrow[\mathrm{CC}], 3.000$} \\
\hline & rs2032582 & $\begin{array}{l}\text { CTR } \\
\text { ADR }\end{array}$ & $\begin{aligned} G & =0.500 \\
T & =0.500 \\
G & =0.523 \\
T & =0.409 \\
A & =0.068\end{aligned}$ & $\begin{aligned} \mathrm{G} / \mathrm{T} & =0.429 \\
\mathrm{G} / \mathrm{G} & =0.286 \\
\mathrm{~T} / \mathrm{T} & =0.286 \\
\mathrm{G} / \mathrm{T} & =0.364 \\
\mathrm{G} / \mathrm{G} & =0.318 \\
\mathrm{~T} / \mathrm{T} & =0.182 \\
\mathrm{~A} / \mathrm{G} & =0.045 \\
\mathrm{~A} / \mathrm{T} & =0.091\end{aligned}$ & $A=0.340 / 741$ & $\begin{array}{l}893 ; \mathrm{T}>\mathrm{A} ; \mathrm{Ser}>\mathrm{Thr} \\
893 ; \mathrm{T}>\mathrm{G} ; \mathrm{Ser}>\text { Ala }\end{array}$ & $\begin{array}{l}\text { Cytoplasmatic; } \\
\text { Alfa-helix chain; third } \\
\text { domain }\end{array}$ & $\begin{array}{l}{[T] \leftrightarrow[A], 2.143} \\
{[T] \leftrightarrow[G], 1.375}\end{array}$ & $\begin{array}{l}{[\mathrm{TT}] \leftrightarrow[\mathrm{TA}], 2.778} \\
{[\mathrm{TT}] \leftrightarrow[\mathrm{TG}], 1.333}\end{array}$ & $\begin{array}{l}{[\mathrm{TT}] \leftrightarrow[\mathrm{AA}], 0.526} \\
{[\mathrm{TT}] \leftrightarrow[\mathrm{GG}], 1.750}\end{array}$ \\
\hline & rs1045642 & $\begin{array}{l}\text { CTR } \\
\text { ADR }\end{array}$ & $\begin{array}{l}T=0.429 \\
C=0.571 \\
T=0.475 \\
C=0.525\end{array}$ & $\begin{array}{l}\mathrm{TT}=0.143 \\
\mathrm{TC}=0.571 \\
\mathrm{CC}=0.286 \\
\mathrm{TT}=0.255 \\
\mathrm{TC}=0.450 \\
\mathrm{CC}=0.300\end{array}$ & $T=0.397 / 864$ & $1145 ; T>C$ Ile $>$ Ile & $\begin{array}{l}\text { Cytoplasmatic, fourth } \\
\text { domain }\end{array}$ & {$[T] \leftrightarrow[C], 0.825$} & {$[\mathrm{TT}] \leftrightarrow[\mathrm{TC}], 0.500$} & {$[\mathrm{TT}] \leftrightarrow[\mathrm{CC}], 0.600$} \\
\hline & rs2235047 & $\begin{array}{l}\text { CTR } \\
\text { ADR }\end{array}$ & $\begin{array}{l}T=0.857 \\
G=0.143 \\
T=0.800 \\
G=0.200\end{array}$ & $\begin{array}{l}\mathrm{TT}=0.714 \\
\mathrm{TG}=0.286 \\
\mathrm{TT}=0.600 \\
\mathrm{TG}=0.400\end{array}$ & $G=0.179 / 389$ & Intron betweer & 25 and 26 exon & {$[T] \leftrightarrow[G], 1.020$} & {$[\mathrm{TT}] \leftrightarrow[\mathrm{TG}], 1.026$} & {$[\mathrm{TT}] \leftrightarrow[\mathrm{GG}], 0.407$} \\
\hline
\end{tabular}


Table 3 | Continued

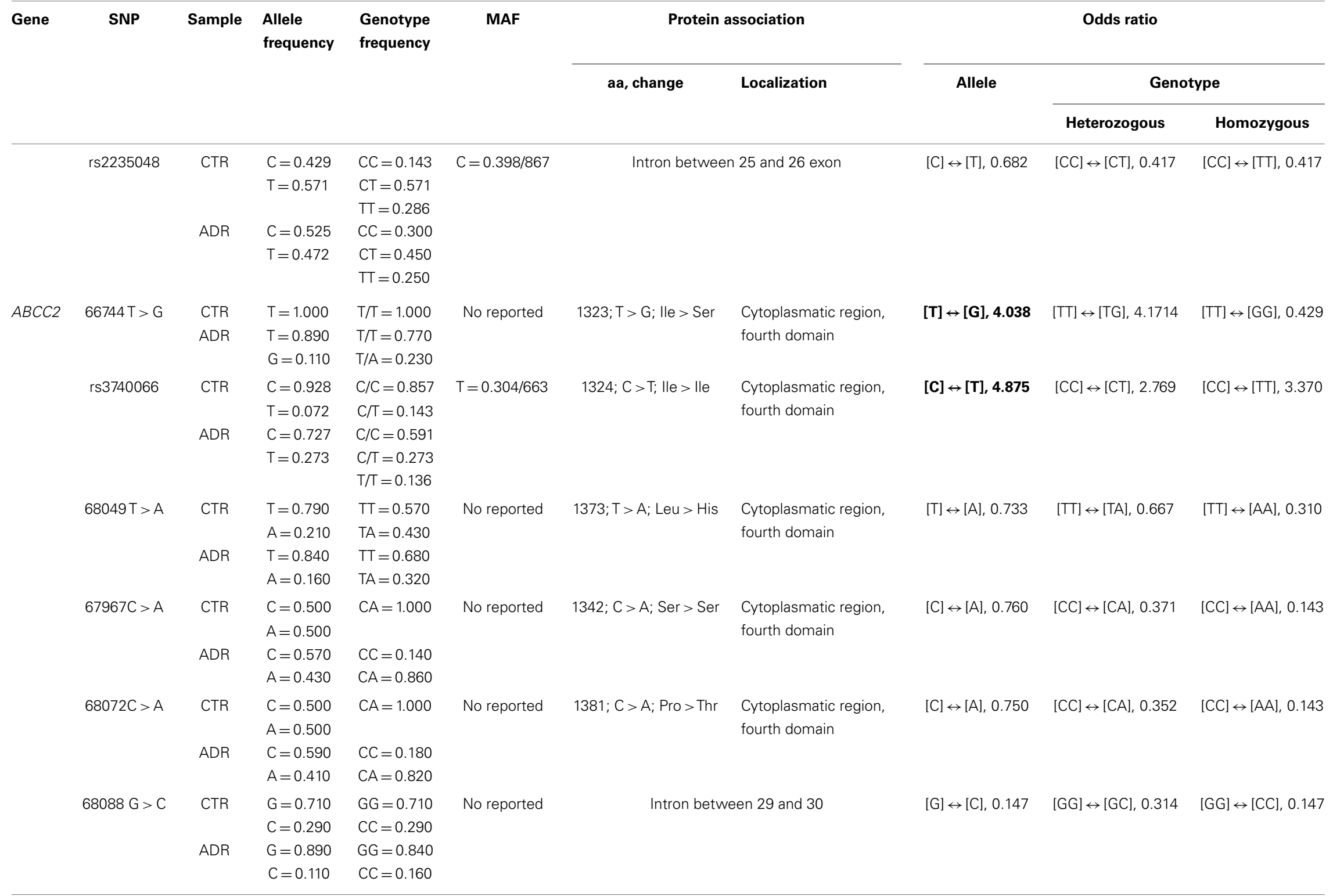

Relative frequencies are presented for the five SNPs reported on NCBI Gene Bank database of ABCB1 and ABCC2 genes among 14 controlled and 44 drug-resistant patients (2n), obtained by direct sequencing. The position indicates the nucleotide change at ABCC2 gene from RefSeqGene NG_011798.1. Amino acid change was obtained from SNP page and its localization from http://www. uniprot.org/ website. Odds ratio (OR) represent the allele risk or mutated using the software on line through the web page http://ihg.gsf.de/cgi-bin/hw/hwa1.pl. Bold font: allele OR> 1.0. DR, drug-resistant; CTR, controlled; MAF, Minor Allele Frequency. 
Table 4 | Genotype and allelic population frequencies of SNPs found in ABCB1 and ABCC2 genes

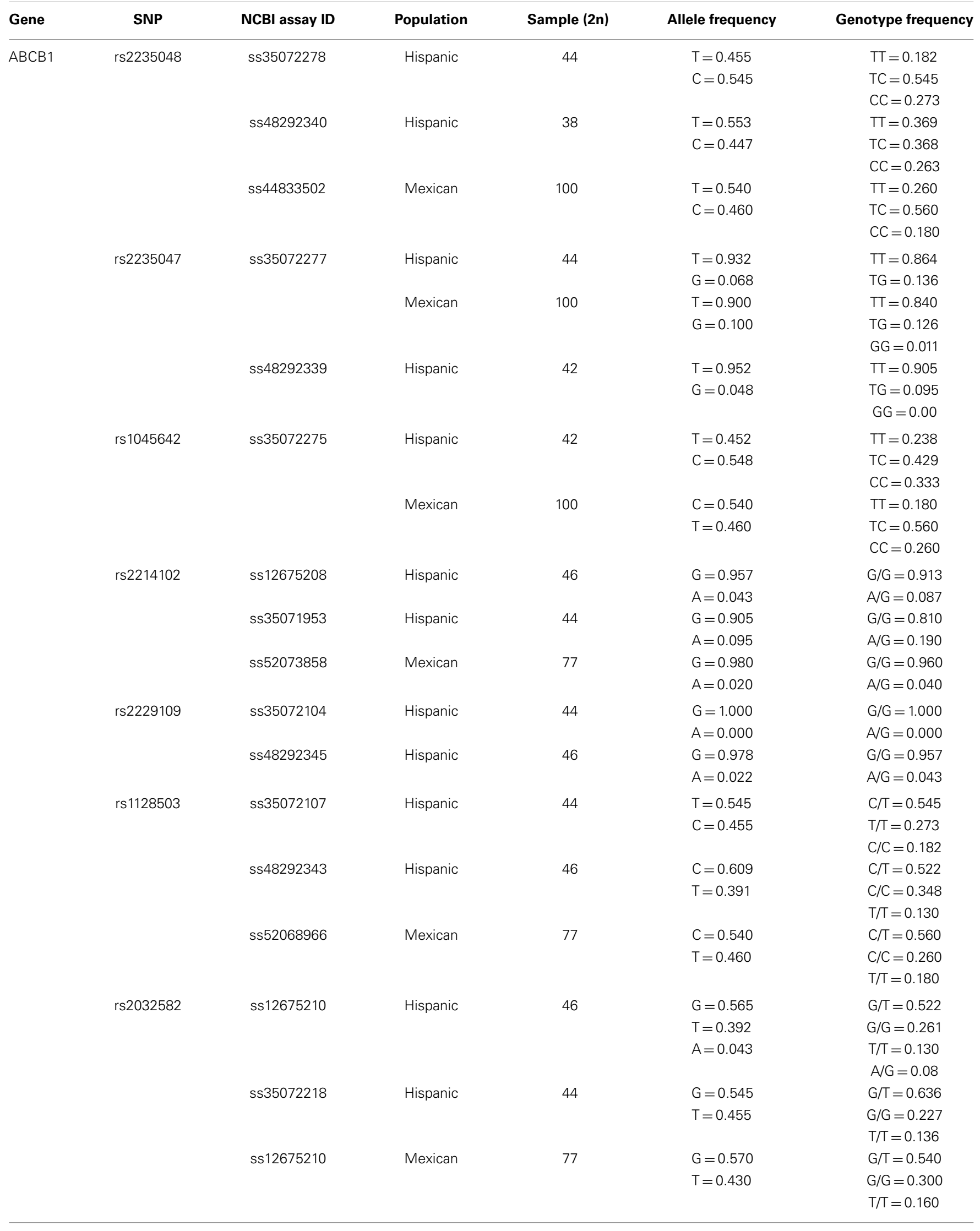


Table 4 | Continued

\begin{tabular}{|c|c|c|c|c|c|c|}
\hline Gene & SNP & NCBI assay ID & Population & Sample (2n) & Allele frequency & Genotype frequency \\
\hline \multirow[t]{2}{*}{$\mathrm{ABCC} 2$} & rs3740066 & ss48292395 & M & 44 & $C=0.614$ & $\mathrm{C} / \mathrm{T}=0.500$ \\
\hline & & & & & $T=0.386$ & $C / C=0.364$ \\
\hline
\end{tabular}

Hispanic populations from ss12675208, ss48292345, ss48292343, ss12675210, and ss48292395 samples belong to HISP-MULTI-NATIONAL Population ID Class, obtained of 23 anonymized individuals of self-described HISPANIC heritage. Hispanic populations from ss35071953, ss35072104, ss35072107 and ss35072218 samples belong to EGP_HISP-PANEL Population ID Class, obtained of 22 individuals with Coriell Cell Repository (CCR) ID. Mexican population belongs to HAPMAP-MEX Population ID Class, obtained of 100 individuals with Mexican ancestry in Los Angeles, California.

at relative frequencies of 0.068 and 0.045 , respectively, but only in drug-resistant patients.

For the SNC $67967 \mathrm{C}>\mathrm{A}$ in exon 29 , no amino acid change (Ser1342Ser) was observed due to nucleotide substitution (Figure 1B); however, SNC 68072C $>$ A resulted in the amino acid change Pro1381Thr (Figure 1D). This allele was present as a heterozygous mutation in both groups ( 1.0 in the CTR group, 0.86 in the ADR group). The SNC 68049T > A in exon 29 resulted in a Leu1373His change (Figure 1C); this allele was heterozygous ( 0.43 in the CTR group, 0.32 in the ADR group), but the wild-type allele predominated in both groups $(>50 \%)$. These nucleotide changes are located in the region of the gene coding for the fourth domain of the protein, corresponding to its cytoplasmic region. In contrast, the SNC 68088G > C (Figure 1E), which is located between exons 29 and 30, occurred in our study population as a homozygous mutation with a relative frequency of 0.29 in the CTR group and a relative frequency of 0.05 in ADR group.

\section{DISCUSSION}

The pediatric epilepsy patients admitted to the Neurology Service, Hospital of Pediatrics, National Medical Center, Century XXI, were referred from family clinics and general hospitals for inadequate control of epileptic seizures. In most cases, the patients received dosage adjustments or changes in drug regimen, drug monitoring, and electroencephalographic studies and were followed closely for adequate control of their seizures. However, some patients continued to interictal epileptiform discharges on EGG and/or the occurrence of seizures, and some gradually deteriorated. The results obtained with a small group of patients who did not respond to at least three different drug regimens but were followed for $4.7 \pm 3.8(\mathrm{CI}=1-14)$ years are presented in this work.

Fagiolino et al. (23) suggested that the quantitation of drugs in saliva can be used to identify drug-resistant patients. The hypothesis presented by these authors is based on the drug concentration circulating in free plasma, which irrigates the glandular capillary tissue, resulting in equilibrium with the aqueous spaces. Considering our results with respect to this hypothesis, we found a lower concentration of free VPA in drug-resistant patients, suggesting a possible deficiency in drug transport in these patients.

The overexpression of P-gp and MRP2 in resected tissue from patients who have undergone surgery for epilepsy suggests that this phenomenon may be conditional upon the presence of polymorphisms in the genes $A B C B 1$ and $A B C C 2$ and not simply to exposure to xenobiotics that recognize these transporter proteins. However, the association between polymorphisms of the $A B C B 1$ and $A B C C 2$ genes and anti-epileptic drug-resistant epilepsy is controversial; SNPs rs1128503 (C1236T), rs2032582 (G2677T/A), and especially rs1045642 (C3435T) in the $A B C B 1$ gene have not shown a clear relationship to anti-epileptic drug-resistant epilepsy from different populations or ethnic groups $(13,24-$ 27). This may be because, as has been reported, SNP rs 1045642 is more relevant as a haplotype with rs1128503 and rs2032582. Zimprichet et al. (28), studying European patients with temporal lobe epilepsy, demonstrated a relationship between the CGC haplotype at SNPs rs1128503, rs2032582, and rs1045642, respectively, and resistance to several AEDs. In another report, Seo et al. (10) demonstrated that Japanese with anti-epileptic drug-resistant epilepsy showed a tendency to possess the haplotype TTT at SNPs rs1128503, rs2032582, and rs1045642 when CBZ was employed. To enable comparison with those reports, haplotype frequency was calculated in our population. Both haplotypes (CGC and TTT) were found in our population. Within each group, the two haplotypes occurred with similar frequencies $(\mathrm{CGC}=0.619, \mathrm{TTT}=0.523$ in $\mathrm{ADR}$ and $\mathrm{CGC}=0.714$, $\mathrm{TTT}=0.714$ in CTR), but both were present at higher frequencies in the CTR group.

For patients who exhibit a mutated allele, OR values can be used to represent relative risk factors among the ADR and CTR patients. The polymorphisms or nucleotide changes, in descending order of risk factor magnitude, are rs2214102> rs2032582 $[\mathrm{T} \leftrightarrow \mathrm{A}]>\mathrm{rs} 2229109>\operatorname{rs} 1128503>\mathrm{rs} 2032582[\mathrm{~T} \leftrightarrow$ $\mathrm{G}]>\mathrm{rs} 2235047$ in $A B C B 1$, and $\mathrm{rs} 3740066>66744 \quad \mathrm{~T}>\mathrm{G}$ in $A B C C 2$; relative to heterozygote genotype rs2032582 $[\mathrm{T} \leftrightarrow \mathrm{A}]>\mathrm{rs} 2214102>\mathrm{rs} 2229109>\operatorname{rs} 2032582 \quad[\mathrm{~T} \leftrightarrow \mathrm{G}]>\mathrm{rs} 11$ $28503>$ rs 2235047 in $A B C B 1$, and $66744 \mathrm{~T}>\mathrm{G}>\mathrm{rs} 3740066$ in $A B C C 2$; finally, with regard to the homozygote genotype, rs1128503 $>$ rs2032582 $[\mathrm{T} \leftrightarrow \mathrm{G}]$ in $A B C B 1$ and $\mathrm{rs} 3740066$ in ABCC2 (Table 3).

Although the number of patients is lower in our work, the results are similar to studies with larger numbers of patients $(25$, 29,30 ), where the lack of association of $A B C B 1$ polymorphisms with anti-epileptic drug resistance (indicated by us as a risk factor) it has been pointed out, including two Indian studies $(31,32)$ and a meta-analysis (26). In contrast, Taur et al. (33) and Siddiqui et al. (34) reported association with anti-epileptic drug resistance. On the other hand, we find that the $A B C C 2$ is a greater risk factor for increased anti-epileptic drug resistance than $A B C B 1$, although 

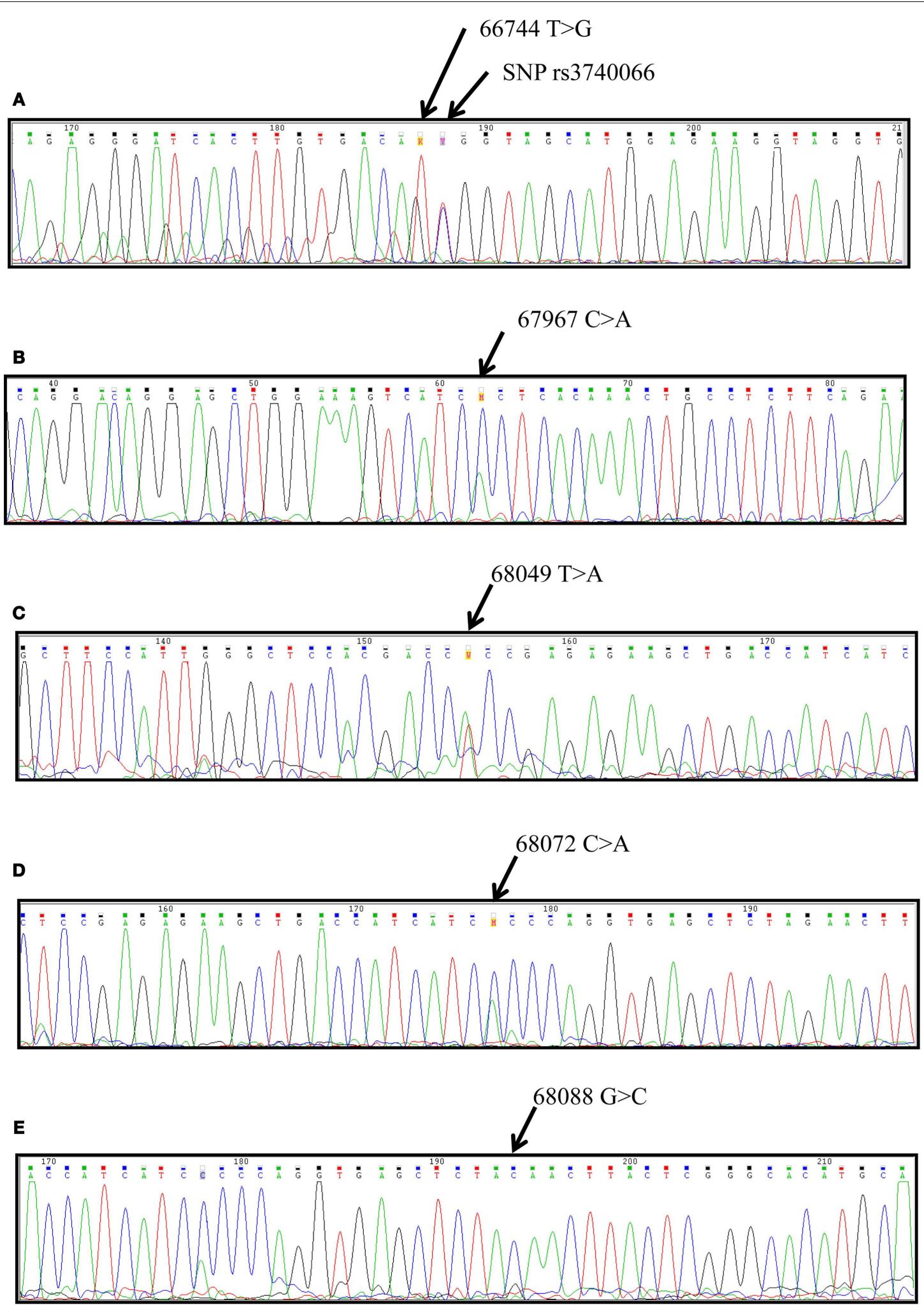

FIGURE 1 | Chromatograms of single-nucleotide changes found in the $A B C C 2$ gene from Mexican pediatric patients with epilepsy. (A) The $66744 \mathrm{~T}>\mathrm{G}$ change in located in exon 28. (B) The $67967 \mathrm{C}>\mathrm{A}$ change in located in exon 29. (C) The 68049 T $>A$ change in located in exon 29. (D) The $68072 \mathrm{C}>\mathrm{A}$ change in located in exon 29. (E) The $68088 \mathrm{G}>\mathrm{C}$ change in located in intron 29. The position indicates the nucleotide change in the ABCC2 gene (RefSeqGene NG_011798.1) 
in previous studies, we only share the SNP rs3740066, not representing a major risk factor as the high activity promoter variant $\mathrm{c}-24 \mathrm{C}>\mathrm{T}$; these data suggest that $A B C C 2$ polymorphism may affect the response to AEDs.

This study employed a different strategy, rigorously selecting pediatric patients with ADR and patients with good seizure control to decrease the potential influence of confounding variables associated with the disease, to develop a study utilizing a non-inferential exploratory search based on the polymorphisms already reported and on unreported new characteristics of the Mexican population. Because our population has been little studied, this will allow us to conduct association studies with new SNPs and AEDs used to treat different forms of epilepsy. To avoid sequencing entire genes, we selected exons containing polymorphisms that have been previously reported in Mexican and Hispanic populations, including the P-gp and MRP2 proteins, which are associated with drug resistance. The most important outcome of this study was the identification of five new changes in the $A B C C 2$; these are $66744 \mathrm{~T}>\mathrm{G}, 67967 \mathrm{C}>\mathrm{A}, 68072 \mathrm{C}>\mathrm{A}$, 68049C $>A$, and G68088C. The nucleotide change 66744T $>\mathrm{G}$ was found only in ADR, and the risk factor associated with it was one of the highest found in the study. Moreover, the genetic variability in SNP rs2032582 in ADR was different and unexpected based on previous reports in the Mexican population in that the A allele was found. This result requires replication in a larger pool of Mexican patients.

\section{REFERENCES}

1. Ngugi AK, Bottomley C, Kleinschmidt I, Sander JW, Newton CR. Estimation of the burden of active and life-time epilepsy: a meta-analytic approach. Epilepsia (2010) 51:883-90. doi:10.1111/j.1528-1167.2009.02481.x

2. World Health Organization (WHO). Epilepsy: Fact Sheet No 999. (2012). Available from: http://www.who.int/mediacentre/factsheets/fs999/en/index.html

3. Kwan P, Baum L, Wong V, Ng PW, Lui CH, Sin NC, et al. Association between ABCB1 C3435T polymorphism and drug-resistant epilepsy in Han Chinese. Epilepsy Behav (2007) 11:112-7. doi:10.1016/j.yebeh.2007.04.013

4. Stepien KM, Tomaszewski M, Tomaszewska J, Czuczwar SJ. The multidrug transporter P-glycoprotein in pharmacoresistance to antiepileptic drugs. Pharmacol Rep (2012) 64:1011-9. doi:10.1016/S1734-1140(12)70900-3

5. Aller SG, Yu J, Ward A, Weng Y, Chittaboina S, Zhuo R, et al. Structure of Pglycoprotein reveals a molecular basis for poly-specific drug binding. Science (2009) 323:1718-22. doi:10.1126/science.1168750

6. Rivers F, O'Brien TJ, Callaghan R. Exploring the possible interaction between anti-epilepsy drugs and multidrug efflux pumps; in vitro observations. Eur J Pharmacol (2008) 598:1-8. doi:10.1016/j.ejphar.2008.09.014

7. Löscher W, Klotz U, Zimprich F, Schmidt D. The clinical impact of pharmacogenetics on the treatment of epilepsy. Epilepsia (2009) 50:1-23. doi:10.1111/j. 1528-1167.2008.01716.x

8. Moerman L, Wyffels L, Slaets D, Raedt R, Boon P, De Vos F. Antiepileptic drugs modulate P-glycoproteins in the brain: a mice study with $11 \mathrm{C}$ desmethylloperamide. Epilepsy Res (2011) 94:18-25. doi:10.1016/j.eplepsyres. 2010.12.013

9. Aronica E, Sisodiya SM, Gorter JA. Cerebral expression of drug transporters in epilepsy. Adv Drug Deliv Rev (2012) 64:919-29. doi:10.1016/j.addr.2011.11.008

10. Seo T, Ishitsu T, Ueda N, Nakada N, Yurube K, Ueda K, et al. ABCB1 polymorphisms influence the response to antiepileptic drugs in Japanese epilepsy patients. Pharmacogenomics (2006) 7:551-61. doi:10.2217/14622416.7.4.551

11. Kwan P, Arzimanoglou A, Berg AT, Brodie MJ, Allen Hauser W, Mathern G, et al. Definition of drug resistant epilepsy: consensus proposal by the ad hoc task force of the ILAE commission on therapeutic strategies. Epilepsia (2010) 51:1069-77. doi:10.1111/j.1528-1167.2009.02397.x

12. Nurmohamed L, Garcia-Bournissen F, Buono RJ, Shannon MW, Finkelstein Y. Predisposition to epilepsy does the ABCB1 gene play a role? Epilepsia (2010) 51:1882-5. doi:10.1111/j.1528-1167.2010.02588.x
13. Haerian BS, Lim KS, Mohamed EH, Tan HJ, Tan CT, Raymond AA, et al. Lack of association of ABCB1 and PXR polymorphisms with response to treatment in epilepsy. Seizure (2011) 20:387-94. doi:10.1016/j.seizure.2011.01.008

14. Haerian BS, Lim KS, Tan HJ, Mohamed EH, Tan CT, Raymond AA, et al. Association between $\mathrm{ABCB} 1$ polymorphism and response to sodium valproate treatment in Malaysian epilepsy patients. Epileptic Disord (2011) 13:65-75. doi:10.1684/epd.2011.0419

15. Kumari R, Lakhan R, Garg RK, Kalita J, Misra UK, Mittal B. Pharmacogenomic association study on the role of drug metabolizing, drug transporters and drug target gene polymorphisms in drug-resistant epilepsy in a north Indian population. Ind J Hum Genet (2011) 1:S32-40. doi:10.4103/0971-6866. 80357

16. Sayyah M, Kamgarpour F, Maleki M, Karimipoor M, Gharagozli K, Shamshiri AR. Association analysis of intractable epilepsy with C3435T and G2677T/A ABCB1 gene polymorphisms in Iranian patients. Epileptic Disord (2011) 13:155-65. doi:10.1684/epd.2011.0443

17. Sterjev Z, Trencevska GK, Cvetkovska E, Petrov I, Kuzmanovski I, Ribarska JT, et al. The association of C3435T single-nucleotide polymorphism, Pgpglycoprotein gene expression levels and carbamazepine maintenance dose in patients with epilepsy. Neuropsychiatr Dis Treat (2012) 8:191-6. doi:10.2147/ NDT.S28285

18. Kim WJ, Lee JH, Yi J, Cho YJ, Heo K, Lee SH, et al. A nonsynonymous variation in MRP2/ABCC2 is associated with neurological adverse drug reactions of carbamazepine in patients with epilepsy. Pharmacogenet Genomics (2010) 20:249-56. doi:10.1097/FPC.0b013e328338073a

19. Ufer M, von Stülpnagel C, Muhle H, Haenisch S, Remmler C, Majed A, et al. Impact of ABCC2 genotype on antiepileptic drug response in Caucasian patients with childhood epilepsy. Pharmacogenet Genomics (2011) 21:624-30. doi:10.1097/FPC.0b013e3283498131

20. Qu J, Zhou BT, Yin JY, Xu XJ, Zhao YC, Lei GH, et al. ABCC2 polymorphisms and haplotype are associated with drug resistance in Chinese epileptic patients. CNS NeurosciTher (2012) 18:647-51. doi:10.1111/j.1755-5949.2012. 00336.x

21. Ramos-Lizana J, Aguirre-Rodríguez J, Aguilera-López P, Cassinello-García E. Recurrence risk after a first remote symptomatic unprovoked seizure in childhood: a prospective study. Dev Med Child Neurol (2009) 51:68-73. doi:10.1111/ j.1469-8749.2008.03124.x

22. Martínez-Juárez IE, López-Zapata R, Gómez-Arias B, Bravo-Armenta E, Romero-Ocampo L, Estévez-Cruz Z, et al. Epilepsia farmacorresistente: uso de la nueva definición y factores de riesgo relacionados. Estudio en población mexicana de un centro de tercer nivel. Rev Neurol (2012) 54:159-66.

23. Fagiolino $\mathrm{P}$, Vázquez $\mathrm{M}$, Maldonado $\mathrm{C}$. Aspectos farmacocinéticos del tratamiento antiepiléptico y su monitoreo mediante el uso de saliva. In: Beas Zárate C, Ureña Guerrero M, et al., editors. En: Tópicos de Actualización en Neurobiología: Excitotoxicidad y Cognición en Enfermedades Neurogenerativas: Aspectos Básicos, Clínicos y Sociales. Guadalajara: Universidad de Guadalajara (2010). p. $381-400$

24. Chen P, Yan Q, Xu H, Lu A, Zhao P. The effects of ABCC2 G1249A polymorphism on the risk of resistance to antiepileptic drugs: a meta-analysis of the literature. Genet Test Mol Biomarkers (2014) 18:106-11. doi:10.1089/gtmb.2013.0362

25. Grover S, Bala K, Sharma S, Gourie-Devi M, Baghel R, Kaur H, et al. Absence of a general association between $\mathrm{ABCB}$ genetic variants and response to antiepileptic drugs in epilepsy patients. Biochimie (2010) 92:1207-12. doi:10.1016/j.biochi. 2010.04.008

26. Haerian BS, Roslan H, Raymond AA, Tan CT, Lim KS, Zulkifli SZ, et al. ABCB1 C3435T polymorphism and the risk of resistance to antiepileptic drugs in epilepsy: a systematic review and meta-analysis. Seizure (2010) 19:339-46. doi:10.1016/j.seizure.2010.05.004

27. Dong L, Luo R, Tong Y, Cai X, Mao M, Yu D. Lack of association between ABCB1 gene polymorphisms and pharmacoresistant epilepsy: an analysis in a western Chinese pediatric population. Brain Res (2011) 1391:114-24. doi:10.1016/j.brainres.2011.03.028

28. Zimprich F, Sunder-Plassmann R, Stogmann E, Gleiss A, Dal-Bianco A, Zimprich A, et al. Association of an ABCB1 gene haplotype with pharmacoresistance in temporal lobe epilepsy. Neurology (2004) 63:1087-9. doi:10.1212/01.WNL. 0000141021.42763.F6

29. Tan NC, Heron SE, Scheffer IE, Pelekanos JT, McMahon JM, Vears DF, et al. Failure to confirm association of a polymorphism in $\mathrm{ABCB} 1$ with multi-drug resistant epilepsy. Neurology (2004) 63:1090-2. doi:10.1212/01.wnl.0000137051. 33486.c7 
30. Szoeke C, Sills GJ, Kwan P, Petrovski S, Newton M, Hitiris N, et al. Multidrugresistance genotype $(\mathrm{ABCB} 1)$ and seizure recurrence in newly treated epilepsy: data from International Pharmacogenetic Cohorts. Epilepsia (2009) 50:1689-96. doi:10.1111/j.1528-1167.2009.02059.x

31. Lakhan R, Misra UK, Kalita J, Pradhan S, Gogtay NJ, Singh MK, et al. No association of ABCB1 polymorphisms with drug-refractory epilepsy in a north Indian population. Epilepsy Behav (2009) 14:78-82. doi:10.1016/j.yebeh.2008. 08.019

32. Vahab SA, Sen S, Ravindran N, Mony S, Mathew A, Vijayan N, et al. Analysis of genotype and haplotype effects of ABCB1 (MDR1) polymorphisms in the risk of medically refractory epilepsy in an Indian population. Drug Metab Pharmacokinet (2009) 24:255-60. doi:10.2133/dmpk.24.255

33. Taur SR, Kulkarni NB, Gandhe PP, Thelma BK, Ravat SH, Gogtay N, et al. Association of polymorphisms of CYP2C9, CYP2C19, and ABCB1, and activity of P-glycoprotein with response to anti-epileptic drugs. J Postgrad Med (2014) 60(3):265-9. doi:10.4103/0022-3859.138739

34. Siddiqui A, Kerb R, Weale ME, Brinkmann U, Smith A, Goldstein DB. Association of multidrug resistance in epilepsy with a polymorphism in the drug-transporter gene ABCB1. N Engl J Med (2003) 348:1442-8. doi:10.1056/ NEJMoa021986
Conflict of Interest Statement: The authors declare that the research was conducted in the absence of any commercial or financial relationships that could be construed as a potential conflict of interest.

Received: 24 July 2014; accepted: 09 September 2014; published online: 09 October 2014.

Citation: Escalante-Santiago D, Feria-Romero IA, Ribas-Aparicio RM, Rayo-Mares D, Fagiolino P, Vázquez M, Escamilla-Núñez C, Grijalva-Otero I, López-García MA and Orozco-Suárez S (2014) MDR-1 and MRP2 gene polymorphisms in Mexican epileptic pediatric patients with complex partial seizures. Front. Neurol. 5:184. doi: 10.3389/fneur.2014.00184

This article was submitted to Epilepsy, a section of the journal Frontiers in Neurology. Copyright (C) 2014 Escalante-Santiago, Feria-Romero, Ribas-Aparicio, Rayo-Mares, Fagiolino, Vázquez, Escamilla-Núñez, Grijalva-Otero, López-García and OrozcoSuárez. This is an open-access article distributed under the terms of the Creative Commons Attribution License (CC BY). The use, distribution or reproduction in other forums is permitted, provided the original author(s) or licensor are credited and that the original publication in this journal is cited, in accordance with accepted academic practice. No use, distribution or reproduction is permitted which does not comply with these terms. 